\title{
Kim AND JonATHAN: AN Individual Tax Planning CASE
}

\author{
Mitchell Franklin
}

Dr. Mitchell Franklin, Ph.D., CPA, Program Director and Assistant Professor of Accounting, Madden School of Business, Le Moyne College, 1419 Salt Springs Road, Mitchell Hall \#212, Syracuse, New York 13214, (315) 445-4703.

\begin{abstract}
The Tax planning case of Kim and Jonathan demonstrates the steps to be taken in the tax research process. These steps are illustrated through tax research to address basic commonly asked questions of individuals as part of standard tax planning. Students are exposed to common individual tax issues such as income inclusion and the deductibility of commonly occurring expenses. This case also requires students in the beginning individual taxation course to communicate research findings in professional form and recognize the different sources of authority utilized in tax research using professional tax research software such as RIA Checkpoint or $\mathrm{CCH}$.
\end{abstract}

Keywords: Tax Planning, Tax Research, Gross Income Inclusions, and Tax Deductions 
DOI: http://dx.doi.org/10.15239/j.brcadvje.2018.03.01.ja06

\section{INTRODUCTION}

A challenge that many faculty members face is the different style of learning faced by the current generation of student (Tempone, Kavanagh, Segal, Hancock, Howieson and Kent, 2012), as well as increased presence of non-traditional students who have expectations of increased handson application (Conte, 1985). As the learning styles of students continue to shift, demands of the profession have also shifted (Abayadeera and Watty, 2014). Employers who hire graduates seek students with improved critical thinking and communication skills (Tempone et.al, 2012; Jackling and De Lange, 2009). The Uniform CPA Examination has responded to the demands of the profession and shifted its focus to measure learning at the higher levels of Bloom's Taxonomy (AICPA, 2016). The shift in focus of the CPA exam should address many current expectation gaps that presently exist between academic institutions, the accounting profession and pre-2017 focus on the exam (Yu and Churyk, 2013). Innovative programs have developed new ways to increase student satisfaction, and also meet the demands of the profession. Williams, Nagle, Rau, Kollar, Yurko, Kannan, Menk and Morris (2015), demonstrate how an accounting program has an increased emphasis on the application of real life case like situations to teach taxation related topics. The use of short case studies has shown to be one innovative method of delivery. Michlitsch and Meg (2002), Nkhoma, Sriatanaviriyakul, Cong and Khai Lam (2013), as well as Ashbaugh and Johnstone (2000) show that the case studies have been an effective tool of learning, specifically in business school disciplines. Bonk and Smith (1998) suggest that assessments with a greater emphasis on higher level learning and critical thinking, such as cases become a significant part of accounting curriculum. Van der Merwe (2013) provides an example to illustrate how a comprehensive case study increased learning and critical thinking in a South African accounting class. 
This case is an example based on the importance referenced within the literature of how one can illustrate crucial topics within the introductory tax course. Not only are students exposed to key topics of strong importance, but also students learn these concepts through research of primary source material. Students demonstrate the learning and application of concepts through communication, a documented area of weakness faced by college graduates as stated in LaFrancois (1992), Tempone et.al, (2012) and Jackling and De Lange (2009).

\section{Case Study}

\section{Client Facts}

Kim and Jonathan are a married couple and reside in New York City. Jonathan owns an upscale men's clothing store with seven stores located throughout New York City, New Jersey and Long Island. Kim is a songwriter/music teacher and just recorded her first album of songs. In addition to writing songs and teaching music at a public school, Kim is also a volunteer at a local food bank. At this food bank, she spends time serving meals to the poor, and establishing relationships with local businesses that could provide both monetary resources and food items as donations. In addition to the food bank, Kim goes into Juvenile detention centers and teaches music to detained children. Kim and Jonathan utilize the 'married filing joint' filing status.

Jonathan has business income also reported on Schedule C, which means he is considered self-employed. As a self-employed business owner, he spent $\$ 5,000$ on suits and clothing that he wears to his shops. These suits are not customized, but simply the most up to date of brands and styles that are sold in his stores. Kim, as her first album is released will perform concerts regionally as a solo performer and nationally on tour as an opening act for other well-known musical groups. On her tours, Kim typically will wear suits, jewelry and high heel shoes. During 
the past year Kim spent approximately $\$ 13,500$ on clothing and Jewelry to be worn while on tour.

The taxpayers have a child named Ava. Ava is a sophomore enrolled at a business school located in the New York City area. Ava was on an athletic scholarship for freshman and sophomore year, but gave up sports to focus on her career following a leg injury. As a result of the lost scholarship Kim and Jonathan will now need to pay all tuition and related expenses, but Ava will still have room and board for free as she has become an RA Advisor. Over the summer, Kim and Jonathan paid for a two-week study abroad trip to Thailand for Ava with a small group to learn about international financial markets. This trip was hosted and coordinated by another business school located in Upstate New York. Tuition was paid directly to the school in Upstate New York.

\section{Preview Complete}

This completes the limited preview of this paper. Please visit the link below to purchase.

\section{Citation Information}

Franklin, Mitchell. "Kim and Jonathan: An Individual Tax Planning Case." BRC Journal of Advances in Education 3, no. 1 (2018): 77-91. http:// dx.doi.org/10.15239/j.brcadvje.2018.03.01.ja06 